Acta vet. scand. $1988,29,357-362$.

From the Department of Toxoplasmosis, State Serum Institute, Copenhagen and the Danish Bilharziasis Laboratory, Charlottenlund, Denmark.

\title{
Effects on in Vitro Growth of Babesia Microti by Cells and Serum from B. Microti and Schistosoma Mansoni Infected Mice
}

\author{
By Jørgen Kurtzhals, Birgitte Jyding Andersen and Niels Ø. Christensen
}

\begin{abstract}
Kurtzhals, J, B. J. Andersen and N. Ø. Christensen: Effects on in vitro growth of Babesia microti by cells and serum from $B$. microti and Schistosoma mansoni infected mice. Acta vet. scand. 1988, 29, 357-362. - The effect of peritoneal macrophages and serum from mice infected with Babesia microti, Schistosoma mansoni and $B$. microti plus $S$. mansoni on the growth of $B$. microti was assessed in short term in vitro cultures using the criterium of rate of incorporation of $\left({ }^{3} \mathrm{H}\right) \mathrm{Hypoxan}$ thine. In the absence of serum, macrophages and supernatants from macrophage cultures failed to affect the in vitro growth of $B$. microti. In contrast, in the absende of macrophages, serum from mice infected with $B$. microti and with $B$. microti plus $S$. mansoni induced a marked inhibition of the in vitro growth of $B$. Microti. The level of inhibition induced by serum from mice infected with both $S$. mansoni and $B$. microti exceeded consistently that induced by serum from mice infected with $B$. microti only. Serum from mice only infected with $S$. mansoni induced a marked increase in the in vitro growth of $B$. microti. These findings suggest a suppression of $B$. microti in concurrently $S$. mansoni-infected mice induced by an immunological specific anti- $B$. microti factor potentiated by the concurrent $S$. mansoni infection. The results do not indicate that activation of the mononuclear phagocytic system is of primary importance in suppression of B. microti in concurrently $S$. mansoni infected mice.
\end{abstract}

rodent model; concurrent infection; in vitro cultures; peritoneal macrophages; $\left({ }^{3} \mathrm{H}\right) \mathrm{Hypoxanthine} \mathrm{incorporation;} \mathrm{growth} \mathrm{inhibition;} \mathrm{poten-}$ tiation of immunological response; immunological specific anti-B. microti factor.

\section{Introduction}

Suppression of a range of blood protozoans in concurrently helminth infected rodents has repeatedly been suggested caused by helminth-induced reticulocytosis and reticulocytopenia combined with a protozoan preference for older red blood cells. However, recent studies on suppression of Babesia microti in Nematospiroides dubius-infected mice have provided strong evidence for the involvement of non-specific activation of the mononuclear phagocytic system in the suppression (Mzembe et al. 1984). Thus, $N$. dubius-induced suppression of concurrent B. microti infection in mice may be blocked by macrophage cytotoxic agents, and macrophages and supernatants from macrophage cultures harvested from $N$. dubius-infected mice may markedly suppress the in vitro growth of B. microti (Mzembe et al. 1984). 
Failure of macrophage cytotoxic agents to affect the suppression of $B$. microti in concurrently Schistosoma mansoni infected mice (Kurtzhals, unpublished) provides the background for the present study in which the effect of peritoneal macrophages and serum from mice infected with $B$. microti, $S$. mansoni and $S$. mansoni plus $B$. microti on the growth of $B$. microti was assessed in short term in vitro cultures. The growth criterium used was rate of incorporation of $\left({ }^{3} \mathrm{H}\right)$ Hypoxanthine (see Goff \& Yunker 1986).

\section{Mouse and parasite material}

Outbred, female albino mice (strain from the National Veterinary Laboratory, Copenhagen, Denmark) weighing 25-30 g ( $>8$ weeks old) at the start of the experiments were used. Percutaneous infection of mice with each 120 cercariae of $S$. mansoni (Puerto Rican strain) took place using the ring method, and the size of the schistosome burdens was determined by perfusion. B. microti (King's strain) was maintained in mice by serial passages. Infections were each time initiated by intraperitoneal injection of $10^{6}$ infected erythrocytes. Levels of parasitaemias were determined by examination of 400 erythrocytes in four different microscopic fields on Giemsa stained blood smears and were expressed as percentage parasitized RBC.

\section{Preparation of macrophage cultures and su- pernatants from macrophage cultures \\ Mice were killed by dislocation and $8 \mathrm{ml}$ he- parinized $(10 \mathrm{iu} / \mathrm{ml})$ phosphate buffered sa- line (PBS, pH 7.4) was injected into the peri- toneal cavity. Following agitation, the peri- toneal contents (medium plus exudate cells) were aspirated, washed with unheparinized PBS by centrifugation followed by resuspen- sion in RPMI 1640 growth medium supple- mented with Gentamycin $(0.6 \mathrm{mg} / \mathrm{ml})$, He-}

pes buffer (25 mmol/l), $\mathrm{NaHCO}_{3}$ (21 $\mathrm{mmol} / \mathrm{l}$ ) and $18 \%$ fetal calf serum heated at $56^{\circ} \mathrm{C}$ for $30 \mathrm{~min}$ to destroy complement activity. Subsequently, $2.5 \times 10^{4}$ peritoneal cells suspended in $10 \mu \mathrm{l}$ growth medium were placed centrally at the bottom of each of the wells of a 96 well Nuclon flat-bottomed microculture plate.

Following incubation for $30 \mathrm{~min}$ at $37^{\circ} \mathrm{C}$ in a $5 \% \mathrm{CO}_{2}$ humidified atmosphere, the wells were carefully washed once with RPMI to remove non-adherent cells. Subsequently, $100 \mu \mathrm{l}$ supplemented growth medium were added to each well, and the plates were cultured for an additional $24 \mathrm{~h}$. Following this incubation, the monolayers of phagocytes, consisting of macrophages mainly, were washed 3 times, and the experiments were subsequently started (see below). Supplemented growth medium containing supernatants from macrophage cultures was obtained following $24 \mathrm{~h}$ cultivation of $5 \times 10^{5}$ peritoneal cells in $600 \mu \mathrm{l}$ supplemented growth medium in the wells of a 24 well Nuclon flatbottomed culture plate. Prior to use, the medium was filtered through a $0.22 \mu \mathrm{m}$ Millipore filter.

Preparation of serum-containing supplemented growth medium and erythrocyte cultures

Blood for preparation of serum-containing supplemented growth medium was obtained by puncture of the orbital vein of anaesthetized mice. After $3 \mathrm{~h}$ at $4^{\circ} \mathrm{C}$, the blood was contrifuged and the serum removed to prepare RPMI supplemented growth medium with $18 \%$ serum. Heparinized blood for preparation of erythrocyte cultures was likewise obtained from the orbital vein of anasthetized mice. The blood was passed through a Sephadex CF-11 column to remove leucocytes, washed twice by centrifugation and resuspended in supplemented RPMI 1640 wi- 
thout serum to obtain a haematocrit of $5 \%$. Parasitized RBC were diluted with unparasitized RBC to obtain a parasitaemia of $6 \%$.

\section{Calculation and determination of parasite- bound radioactivity}

To each well containing a macrophage culture (see below) $100 \mu \mathrm{l}$ supplemented growth medium with $18 \%$ serum of different types (see below) was added together with $50 \mu \mathrm{l}$ parasitized erythrocyte suspension resulting in a final Haematocrit of $1.7 \%$ and a final serum concentration of $12 \%$. To other wells without macrophages, supernatants from macrophage cultures of different types (see below) were added together with $50 \mu \mathrm{l}$ parasitized erythrocyte suspension. Either immediately or following $24 \mathrm{~h}$ incubation, $10 \mu \mathrm{Ci}$ $\left({ }^{3} \mathrm{H}\right)$ Hypoxanthine (Nuclear, England) in 10 $\mu$ RPMI 1640 was added to each well. After another $18 \mathrm{~h}$ the erythrocytes were harvested using a Titertek Automatic Cell Harvester onto glass fiber filters, washed for $30 \mathrm{~s}$ with distilled water and for $60 \mathrm{~s}$ with $0.9 \% \mathrm{NaCl}$. Subsequently they were dried and placed in toluene scintillation fluid (Aqualuma), and counted for $2 \mathrm{~min}$ in a Isocop 200 beta liquid scintillation counter. The erythrocyte harvest procedure apparently did not disturb the macrophage monolayer. The radioactivity counting figure was taken as a measure of the growth of $B$. microt $i$ in the in vitro culture (see Goff \& Yunker 1986).

\section{Experimental plan}

Macrophages and serum were obtained day 11 following $B$. microti challenge of mice harbouring 8-week-old primary $S$. mansoni infections. Macrophages and serum were also obtained from corresponding groups of mice infected with either $B$. microti or $S$. mansoni and from a corresponding group of parasite-free mice. The $B$. microti parasitaemia at harvest of serum and cells was $9 \pm 3$ and $43 \pm 7 \%$ in the double and single infected groups, respectively. The number of worm pairs per mouse was in the range of 8 to 12 in both groups of $S$. mansoni-infected mice.

Serum from either of the 4 groups of mice was added to wells either harbouring no macrophages or macrophages from either of the four groups resulting in a total of 20 combinations. For each combination 5 wells were prepared with parasitized RBC and 1 with unparasitized RBC acting as a negative control (see also Fig. 1). In other experiments (see Table 1) supernatants from macrophage cultures from either of the groups of mice were added to macrophage-free wells harbouring either parasitized (5 replicate) or unparasitized (1 replicate) RBC.

The growth inhibition was calculated as

$\mathrm{I}(\%): 1-\frac{\text { Cpm (combination) - Cpm (control) }}{\text { Cpm (standard) - Cpm (control) }} \times 100$ Cpm (combination) is the mean cpm (counts per min corrected for background counts) count from the 5 wells with parasitized blood of a given combination of macrophages and serum, cpm (control) is the mean cpm count from all wells with unparasitized blood, and cpm (standard) is the mean count for the 5 wells with no macrophages and with serum from uninfected mice. In Exp. 1 (18 $\mathrm{h}$ incubation) the cpm (standard) was $3079 \pm 292$ and the cpm (control) was 196 \pm 55. In Exp. 2 (42 $\mathrm{h}$ incubation) the cpm (standard) was $2106 \pm 21$ and the cpm (control) was $212 \pm 56$. The cpm (standard) in the macrophage supernatant experiments, which was the mean cpm from the 5 wells with supernatants from cultures of macrophages from uninfected mice, was $3589 \pm$ 223 and $1655 \pm 90$ after 18 and $42 \mathrm{~h}$ of incubation, respectively.

Statistical analyses of the results obtained were made using a two-way analysis of variance. A p-value of $<0.05$ was considered significant. 
Table 1. Percentage inhibition of in vitro growth of Babesia microti by supernatants from cultures of macrophages harvested from Schistosoma mansoni-, B. microti-, and S. mansoni plus B. microti-infected mice as assessed by rate of incorporation of $\left({ }^{3} \mathrm{H}\right)$ Hypoxanthine ${ }^{a}$.

\begin{tabular}{lccc}
\hline $\begin{array}{l}\text { Hours of } \\
\text { growth }\end{array}$ & \multicolumn{3}{c}{$\begin{array}{l}\text { Supernatants from cultures of macrophages } \\
\text { harvested from mice infected with }\end{array}$} \\
\cline { 2 - 4 } & B. microti & S. mansoni & B. microti + S. mansoni \\
\hline 18 & $-8^{\mathrm{b}}$ & -8 & -2 \\
42 & -4 & 3 & -16 \\
\hline
\end{tabular}

a Control values comprise growth in presence of supernatants from cultures of macrophages harvested from uninfected mice; level of statistical significance of effect on growth: $p>0.05$

${ }^{b}$ Negative figure indicates percentage growth enhancement

c $\left({ }^{3} \mathrm{H}\right)$ Hypoxanthine added either immediately ( $18 \mathrm{~h}$ growth) or after $24 \mathrm{~h}(42 \mathrm{~h}$ growth), and assessment of radioactivity took place after another $18 \mathrm{~h}$.

\section{Results}

Results from representative series of experiments are presented in Fig. 1 and Table 1. From Fig. 1 it appears that, in the absence of serum from infected mice, macrophages harvested from mice infected with $S$. manso$n i, B$. microti or $S$. mansoni plus $B$. microti failed to affect to a statistically significant level the in vitro growth of $B$. microti. In contrast, in the absence of macrophages, serum from $B$. microti and $S$. mansoni plus $B$. microti infected mice induced a marked and statistically significant suppression of the in vitro growth of $B$. microti. However, combining serum from mice infected with $B$. microti only and from mice infected with both $B$. microti and S. mansoni with any of the different types of macrophages did not increase further the level of suppression of growth of $B$. microti in vitro. The level of growth inhibition induced by serum from $S$. mansoni plus $B$. microt $i$ infected mice exceeded consistently and to a statistically significant level the growth inhibition induced by serum obtained from mice only infected with $B$. microti. Surprisingly, serum from $S$. mansoni infected mice either alone or in combination with any of the types of macrophages induced a very pronounced increa-

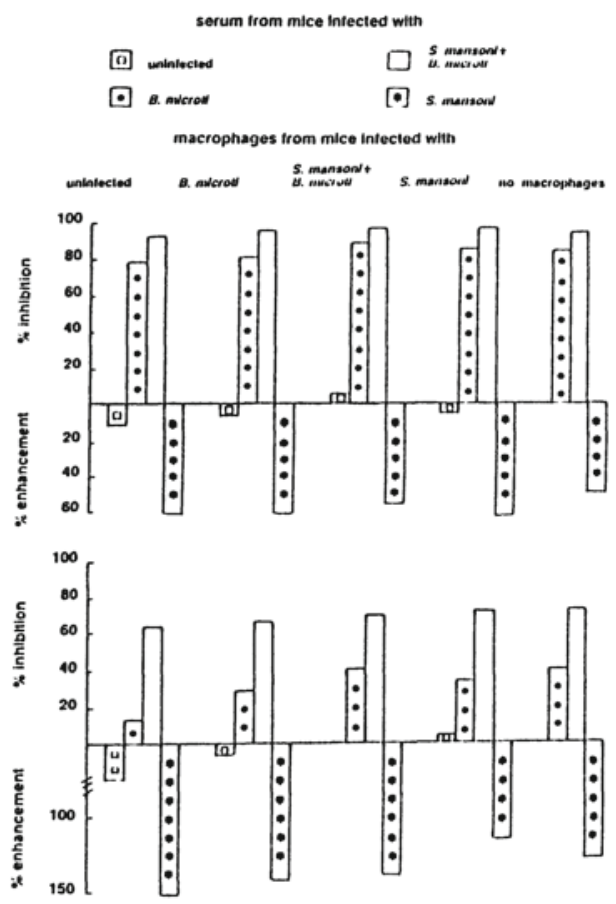

Figure 1. Effect on in vitro growth of Babesia microti by macrophages and/or serum from uninfected and B. microti-, Schistosoma mansoni-, and S. mansoni plus $B$. microti-infected mice during periods of growth of 18 (top) and 42 (bottom) h as assessed by rate of incorporation of $\left({ }^{3} \mathrm{H}\right) \mathrm{Hypoxanthine} \mathrm{(control}$ values comprise growth in the absence of macrophages and with serum from uninfected mice). 
se in the in vitro growth rate of $B$. microti. Finally, from Table 1 it appears that supernatants from cultures of macrophages harvested from $S$. mansoni and/or B. microti infected mice failed to affect negatively the in vitro growth of $B$. microti. In fact, in most cases an enhancement, although not significant, was observed in the in vitro growth rate. The overall results obtained in the experiments presented were confirmed in a series of other similar experiments.

\section{Discussion}

Suppression of infections with blood protozoans by concurrent helminth infection in experimental rodent hosts is a common finding in laboratory experiments (i.e. see Long et al. 1981, Ngwenya 1982, Bailenger \& Guy 1982, Lwin et al. 1982, Mzembe et al. 1984, Fagbemi et al. 1985 a, b). The suggestion that suppression of $B$. microti and other blood protozoans by concurrent helminth infection could be due to helminth-induced changes in the erythrocyte kinetics combined with a protozoan preference for erythrocytes of specific age categories appears not supported experimentally. Thus, different levels of suppression of $B$. microti have been demonstrated in different strains of Trypanosoma brucei-infected mice experiencing comparable anaemia levels (Millott \& Cox 1985), and a marked suppression of B. microti in $N$. dubius-infected mice (Mzembe et al. 1984) and of Plasmodium berghei in Trichinella spiralis infected mice (Ngwenya 1982) may occur in spite of only low levels of anaemia. It is not least noteworthy that a severe anamia induced by repeated bleeding failed to affect the course of $B$. microti infection in mice despite the fact that the age profile of the red cell populations changed markedly (Fagbemi, unpublished). In fact, the other commonly forwarded suggestion of helminth-induced suppression of concur- rent blood protozoan infections being mediated by immunological non-specific activation of the mononuclear phagocytic system was supported experimentally by Mzembe et al. (1984) working on the N.dubius/B. microti model.

Evidence has thus been presented that helminth induced suppression of concurrent blood protozoan infections could simply resemble the macrophage mediated non-specific resistance to blood protozoan infection induced by a variety of agents like Corynebacterium parvum, BCG and zymosan (see Cox 1987). However, the findings from the present study on the $S$. mansoni/B. microti model point to a more complex mechanism where the suppression was mediated by a serum-soluble factor and not by the direct effects of macrophages. Failure by serum from $S$. mansoni infected mice to suppress in vitro growth of $B$. microti (growth was actually markedly increased) and the consistent finding that suppression induced by serum from $S$. mansoni plus $B$. microti infected mice exceeded the suppression induced by serum from mice infected with $B$. microt $i$ only might indicate that the suppression is mediated by an immunological specific antiB. microti factor potentiated by concurrent $S$. mansoni infection. No evidence was obtained in the present study for any direct involvement of the macrophage in the suppression of B. microti in $S$. mansoni infected mice. However, an indirect effect of the $S$. mansoni activated macrophage cannot be excluded. Thus, the potential of the $S$. mansoni activated macrophage to increase the specific immunological response to $B$. microti for example by improving the presentation of antigens to B-lymphocytes should be examined. 


\section{Acknowledgements}

This study was supported by grants from the Carlsberg Foundation and the Danish Natural Science Research Council.

\section{References}

Bailenger J, Guy M: Interactions de deux parasitoses associées chez le rat: Plasmodium berghei et Strongyloides ratti. (Interactions in concurrent parasite infections in the rat: Plasmodium berghei and Strongyloides ratti). Ann. Parasitol. Hum. Comp. 1982, 57, 513-526.

Cox FEG: Interactions in protozoan infections. Int. J. Parasitol. 1987, 17, 569-575.

Fagbemi B, Christensen NØ, Nansen P: Suppression of Babesia microti infection in mice concurrently infected with Fasciola hepatica. Vet. Parasitol. 1985a, 17, 101-110.

Fagbemi B, Christensen NO, Nansen P: Suppression of Babesia microti infection in mice concurrently infected with Schistosoma mansoni. Acta vet. scand. 1985b, 26, 191-204.

Goff WL, Yunker CE: Babesia bovis: Increased percentage parasitized erythrocytes in cultures and assessment of growth by incorporation of $\left({ }^{3} \mathrm{H}\right)$ Hypoxanthine. Exp. Parasitol. 1986, 62, 202-210.

Long $E$, Lwin $M$, Targett $G$, Doenhoff $M$ : Factors affecting the acquisition of resistance against Schistosoma mansoni in the mouse. VIII. Failure of concurrent infections with Plasmodium chabaudi to affect resistance to reinfection with $S$. mansoni. Ann. trop. Med. Parasitol. 1981, 75, 79-86.

Lwin $M$, Last $C$, Targett GAT, Doenhoff MJ: Infection of mice concurrently with Schistosoma mansoni and rodent malarias: contrasting effects of patent $S$. mansoni infections on Plasmodium chabaudi, $P$. yoelii and $P$. berghei. Ann. trop. Med. Parasitol. 1982, 76, 265-273.

Millott SM, Cox FEG: Interactions between Trypanosoma brucei and Babesia spp. and Plasmodium spp. in mice. Parasitology 1985, 90, 241254.
Mzembe SAT, Lloyd S, Soulsby EJL: Macrophage mediated resistance to Babesia microti in Nematospiroides dubius-infected mice. Z. Parasitenkd. 1984, 70, 753-761.

Ngwenya BZ: Enhanced resistance to Plasmodium berghei in mice previously infected with Trichinella spiralis. Parasite Immunol. 1982, 4, 197 207.

\begin{abstract}
Sammendrag
Effekten af celler og serum fra Babesia microti og Schistosoma mansoni inficerede mus pà in vitro voekst af B. microti.

Effekten af peritoneale makrofager og serum fra mus inficerede med Babesia microti, Schistosoma mansoni, og B. microti plus $S$. mansoni på væksten af $B$. microti blev undersøgt i korttids in vitro-kulturer under anvendelse af $\left({ }^{3} \mathrm{H}\right) \mathrm{Hypoxanthine} \mathrm{inkorpo-}$ rering som vækstkriterium. I fravær af serum påvirkede hverken makrofager eller supernatanten fra makrofagkulturer in vitro væksten af $B$. microti. I modsætning hertil forårsagede serum fra mus inficerede med $B$. microti og med $B$. microti plus $S$. mansoni i fravær af makrofager en markant hæmning af væksten af $B$. microti in vitro. Graden af hæmning forårsaget af serum fra $S$. mansoni plus $B$. microti inficerede mus overgik konsekvent graden af hæmning forårsaget af serum fra B. microti inficerede mus. Serum fra $S$. mansoni inficerede mus forårsagede en markant forøgelse i in vitro væksten af $B$. microti. Disse resultater peger på at in vivo suppression af $B$. microti i mus med en samtidig $S$. mansoni infection kan være forårsaget af en immunologisk specifik anti-B. microti faktor der potentieres gennem samtidig tilstedeværelse af S. mansoni infektion. Resultaterne tyder ikke på at non-specifik aktivering af det mononukleære fagocytiske system er af primær betydning for suppression af $B$. microti i mus med samtidig $S$. mansoni infektion.
\end{abstract}

(Received October 20, 1987; accepted February 5, 1988).

Reprints may be requested from: Niels Ørnbjerg Christensen, Danish Bilharziasis Laboratory, Jægersborg Allé 1 D, DK-2920 Charlottenlund, Denmark. 